\title{
Kontrowersje wokół deizmu
}

\begin{abstract}
The controversies in the title of this paper are related to an attempt of answering the following questions: who was a deist and what does deism express, as well how is it related to atheism, agnosticism, pantheism and theism? The article by professor Antoni Szwed included in this very volume of "Humaniora" makes a voice in the debate on the issue of deism of Matthew Tindal and several other contemporary deists. I do not intend to argue with the views of that author. It is however necessary to say clearly that in the issue of those deists, as well many others opinions and views may vary in often even radically different. It is to be stressed out that the author of this article had presented his opinion on the issue in the title, but also that he presented in it only a fraction of this very comples problem which was and still is deism. For a better understanding of this problem we may recall several other deists and present the controversies surrounding them.
\end{abstract}

Keywords: atheism, agnosticism, deism, pantheism, theism

T

ytułowe kontrowersje związane są z próbami odpowiedzi na pytania dotyczące tego, kto był deistą, w czym się wyrażał i wyraża deizm oraz jak się on ma do ateizmu, agnostycyzmu, panteizmu i teizmu. Zamieszczony w tym numerze „Humaniory” artykuł Antoniego Szweda stanowi ważny głos w dyskusji na temat deizmu Matthew Tindala oraz kilku innych współczesnych mu deistów. Nie zamierzam tutaj polemizować z ustaleniami jego autora. Trzeba jednak wyraźnie powiedzieć, że zarówno w kwestii tych deistów, jak i wielu innych opinie oraz oceny są różne i w niejednym przypadku radykalnie rozbieżne ${ }^{1}$. Rzecz jednak nie tylko w tym,

${ }^{1}$ Por. przykładowo: W. Hudson, D. Luccl, J.R. Wilgelsworth (eds), Atheism and Deism Revalued. Heterodox Religoius Identities in Britain, ASHGATE Press, Burligton 2014. 
że autor tego artykułu przedstawił w nim swoje stanowisko w tytułowej kwestii, ale także w tym, że przedstawił w nim jedynie wycinek tego złożonego problemu, jakim był i jest deizm. Do jego lepszego zrozumienia może się przyczynić przedstawienie kilku innych deistów oraz związanych z nimi kontrowersji.

Wyjdę od kontrowersji terminologicznych. Różne znaczenia nadawane pojęciu deism (od łac. Deus - Bóg) nie pojawiły się od razu, bowiem przez dłuższy czas było ono stosowane zamiennie z wywodzącym się z języka greckiego pojęciem teism (oznaczającym również Boga). Kontrowersje dotyczą już jednak historycznego momentu, w którym zaczęto wyraźniej odróżniać znaczenia tych terminów. Zdaniem Johna Orra miało to miejsce w XVII wieku i związane było z pojawieniem się takich angielskich teologów i filozofów, którzy głosili wprawdzie wiarę w istnienie Stwórcy, ale jednocześnie utrzymywali, że uczynił on świat stworzony na tyle samowystarczającym, że jego istnienie i funkcjonowanie może go pozostawić tym mocom, w które go wyposażył². Takie jego datowanie i umiejscawianie stawia pod znakiem zapytania opublikowana w 1564 r. Instrukcja chrześcijańska protestanckiego teologa Pierre’a Vireta. Jej autor stwierdza w niej, iż „słyszał, że jest taka grupa osób, która nazywa siebie deistami i która chce w ten sposób przeciwstawić się ateistom, to znaczy tym, którzy są bez Boga”. Jego zdaniem deiści „z pewnością wierzą, że istnieje jakiś Bóg, którego uznają za stwórcę nieba i ziemi [...]; jednak jeśli chodzi o Jezusa Chrystusa, to wiedzą tylko tyle, że On istnieje”, natomiast przekazy ewangelistów i apostołów uznają za mity. Zdaniem tego teologa sprawia to, że nie ma większej różnicy między nimi a ateistami ${ }^{3}$.

W XVII i XVIII stuleciu, przynajmniej jeśli chodzi o deistów angielskich, znaczenie tego terminu stało się bardziej jednoznaczne. Jednak nie na tyle, aby można było bez trudności odróżnić deistów od teistów i ateistów, a nawet, aby można było z pełnym przekonaniem powiedzieć, że ci pierwsi sami potrafili się odróżnić od jednych i drugich. Takie próby były jednak wówczas podejmowane, a ich przykładem mogą być poglądy Herberta z Cherbury (1583-1648), poety i filozofa, autora rozprawy pt. De Veritate, prout distinguitur a revelatione, versimili, possible et falso (1624) ${ }^{4}$. W literaturze można się spotkać z opinią, że był on „ojcem angielskiego deizmu”5. Można jednak również znaleźć w niej pogląd, że jeśli nawet uznać go za deistę, to był raczej nietypowym deistą. W odróżnieniu bo-

\footnotetext{
${ }^{2}$ Por. J. Orr, English Deism: Its Roots and Its Fruits, 1934, s. $13 \mathrm{nn}$.

${ }^{3}$ Por. P. Viret, Instruction Chrétienne en la doctrine de la foi et de l'Évangile, Editions l'Age d'Homme, Paris 2004.

${ }^{4}$ Por. Herbert of Cherbury, De Veritate, J.W. Arrowsmith, Bristol 1937. W 1663 r. w Amsterdamie opublikowane zostało jego dzieło zatytułowane De religione gentilium errorumque apud eos causis, które Hume przedstawiał jako „naturalną historię religii”.

5 Ch. Hugh, Herbert of Cherbury, Edward Herbert, Baron, „Encyclopædia Britannica” 13, wyd. 11, Cambridge University Press 1911, ss. 340-341.

${ }^{6}$ Por. P. Gay, Deism: An Anthology, Princeton: D. Van Nostrand Company, Inc., 1968, s. $30 \mathrm{nn}$.
} 
wiem od deistów typowych wierzył on nie tylko w działanie Opatrzności, ale także w cuda, objawienia, boskie natchnienia, a nawet w dawane mu bezpośrednio znaki z Nieba ${ }^{7}$. Bezdyskusyjne zdaje się być jednak przynajmniej to, że miał negatywny stosunek do ateistów i ateizmu, a nawet utrzymywał, że prawdziwi ateiści w gruncie rzeczy nie istnieją i nie mogą istnieć, bowiem ci, którzy się za nich uważają, najpierw przypisują Bogu fałszywe atrybuty, a później twierdzą, że wyposażona w nie Istota nie może istnieć ${ }^{8}$. To demaskowanie ateistów i ateizmu nie zapobiegło zresztą umieszczeniu jego dzieła na kościelnym indeksie ksiąg zakazanych - co to bowiem jest za chrześcijanin, który wprawdzie wierzy w Boga, a nawet pada na kolana i prosi o danie mu czytelnego znaku (m.in. w kwestii opublikowania jego kontrowersyjnego dzieła), ale indywidualizuje swoje relacje z Bogiem do tego stopnia, że staje się zbędne korzystanie w nich z pośrednictwa Kościoła.

Spore kontrowersje wywołuje również łączenie z deizmem takich osób, jak Henry St John Bolingbroke (1678-1751) i Aleksander Pope (1688-1744). Z takim łączeniem mamy do czynienia m.in. w Myśli europejskiej XVIII wieku Paula Hazarda - o pierwszym z nich autor tego dzieła napisał, że „utraciwszy wiarę, odrzucił ateizm” i „stworzył sobie filozofię pośrednią, którą miał propagować Pope”, natomiast o drugim, że jego „deizm nie jest deizmem Woltera”, natomiast jest „to deizm poetycki, deizm w stanie jeszcze mgławicowym”. W literaturze można spotkać się z opinią, że Bolingbroke’a należałoby uznać za takiego anglikańskiego wiga, który usiłował wyeliminować z anglikanizmu to, co było w nim „absurdalne i wstrętne”, a w polityce pragnął przekształcenia angielskiej monarchii konstytucyjnej w oligarchię ${ }^{10}$. Natomiast Pope’a uznaje się za takiego wielkiego poetę, który nie tylko wychował się w katolickiej rodzinie, ale także do końca życia pozostał katolikiem; potwierdzeniem tego ma być m.in. jego poemat filozoficzny pt. Esej o człowieku ${ }^{11}$. Pozostaje jednak faktem, że tacy oświeceniowi deiści jak Voltaire znajdowali zarówno u tego pierwszego, jak i u tego drugiego uzasadnienie dla swojego deizmu, a tacy oświeceniowi ateiści jak Paul Thiry Holbach znajdował u Bolingbroke’a argumenty mające przemawiać za jego ateizmem (?!).

${ }^{7}$ Por. J. Waligore, The Piety of the English Deists, „Intellectual History Review” 2(22)/2012, s. $181 \mathrm{nn}$.

${ }^{8}$ Por. D. Bergman, A History of Atheism in Britain, Routledge, London and New York 2013, s. $30 \mathrm{nn}$.

9 „Trafnie dostrzegano u niego pogaństwo, panteizm, fatalizm i resztki katolicyzmu: mówił bowiem o doskonale szczęśliwym stanie natury, który ulega skalaniu, co sugerowało wiarę w grzech pierworodny”. Por. P. Hazard, Myśl europejska w XVIII wieku. Od Monteskiusza do Lessinga, PIW, Warszawa1972, s. 352 i in.

${ }^{10}$ B. Disraeli, Whigs and Whiggism: political writings, Macmillan, 1914, s. $218 \mathrm{nn}$.

${ }^{11}$ Zdaniem Ernsta Cassirera poemat ten jest próbą pokazania „drogi człowieka do Boga” człowieka usytuowanego między „aniołami i bestiami tego świata”, oraz drogi prowadzącej poprzez „wielki łańcuch bytów”. Por. E. Cassirer, An essay on man; an introduction to a philosophy of human culture, Yale University Press 1944. 
Ważnym głosem w dyskusji na temat oświeceniowego deizmu są Dialogi o religii naturalnej Davida Hume’a (1711-1776). Ważnym, ale nie jednoznacznym. O ile bowiem ich autor miał w miarę wyrobiony pogląd zarówno na temat deizmu, jak i teizmu oraz ateizmu, to jednak do każdego z nich zgłaszał swoje zastrzeżenia i - co w tej sytuacji jest w zrozumiałe - nie deklarował się jednoznacznie po stronie żadnego z nich. Przypomnę, że uczestnikami tych dialogów są trzy fikcyjne postacie: Filon, Kleantes i Demea. Żadna z nich nie opowiada się za którąś z tradycyjnych religii - ich wierzenia nazywane są przez nich „ciemnotą” i uznawane za rzecz niegodną ludzi rozumnych. Jednak tym rozumnym ludziom „,wolno różnić się w poglądach. Jeśli nawet nie doprowadzi to do żadnego rozstrzygnięcia, to przynajmniej dostarczy to rozrywki i przyjemności” (jak można się domyślać: intelektualnej). I faktycznie, różnią się oni w swoich poglądach m.in. w takich zasadniczych kwestiach jak istnienie Boga.

Stosunkowo najbardziej sceptyczne stanowisko w tej kwestii zajmuje Filon, a najbardziej ostrożne Demea. Z kolei Kleantes reprezentuje opcję „złotego środka” między tymi stanowiskami. Wypowiada się on wprawdzie krytycznie, wręcz sarkastycznie o tradycyjnych wierzeniach w Boga, a nawet wskazuje historyczne okoliczności, w których się one narodziły (pojawić się one miały „w czasach najgłębszej niewiedzy”, a później „chrześcijańska filozofia połączyła je z popularną religią i uczyniła powszechnie przyjętą rzeczą”), jednak twierdzi również, że „nic nie istnieje bez przyczyny; zaś czymkolwiek jest pierwotna przyczyna wszechświata, nazywamy ją Bogiem i z czcią przypisujemy jej wszystkie doskonałości”. Ów Bóg „to jednak nic innego niż taki Wielki Mechanik, który skonstruował świat i wprawił go w ruch”, a ów świat „to nic innego jak wielka maszyna złożona z nieskończonej ilości mniejszych maszyn, które z kolei same są złożone w stopniu wyższym niż zmysły i zdolności ludzkie mogą to dojrzeć i wyjaśnić”12.

Takie stanowisko stosunkowo dobrze oddaje myśl przewodnią deizmu brytyjskiego. Jeśli przyjąć, że Kleantes wyraża poglądy samego Hume’a, to autora tych Dialogów można byłoby uznać za deistę ${ }^{13}$. Można byłoby, gdyby nie towarzyszące

12 „Najprzeróżniejsze te maszyny, a nawet najdrobniejsze ich części, dopasowane są do siebie z taką dokładnością, która wprawia w zachwyt każdego, kto im się kiedykolwiek przyjrzał. Widoczne w całej naturze osobliwe przysposobienie środków do celu przypomina zupełnie, choć znacznie przewyższa, wytwory ludzkiej pomysłowości, zdolności celowego działania myśli, mądrości i inteligencji”. Por. D. Hume, Dialogi o religii naturalnej, PWN, Warszawa 1962, s. 23 i in.

${ }^{13}$ Tak jest on zresztą przedstawiany przez Gertrudę Himmelfarb. Por. G. Himmelfarb, The Roads to Modernity. The British, French, and American Enlightenments, Alfred A. Knoff, New York, 2004, s. 39 nn. Zdaniem Davida Bermana wyrazicielem stanowiska Hume’a jest jednak nie Kleantes, lecz Filon, a to oznacza, że autorowi Dialogów bliżej było do ateizmu niż deizmu. Przyznaje on jednak, że Hume przynajmniej deklaratywnie zgłaszał swoje votrum seperatum wobec ateizmu (nie tylko w Dialogach, ale także, a nawet przede wszystkim w swojej Historii naturalnej religii) oraz powątpiewał w to, czy prawdziwi ateiści faktycznie mogą istnieć. Dla ilustrowania tych jego wątpliwości przywołuje on opis pobytu Hume’a w paryskim salonie głośnego ateisty tamtych czasów, barona P. T. Holbacha - gdy ten usłyszał od swojego gościa, 
temu wywodowi Kleantesa takie zastrzeżenia, których bezzasadności nie potrafi on w gruncie rzeczy wykazać i uczestnicy tych dialogów godzą się w końcu na to, że wprawdzie „Kleantes bardziej od pozostałych zbliżył się do prawdy”, ale jednak do jej osiągnięcia jeszcze mu sporo brakuje. To z kolei można byłoby uznać za pewien „ukłon” w kierunku ateizmu. Można byłoby, gdyby nie zgłoszone w tych Dialogach stanowcze votum separatum wobec ateizmu, wyrażające się w generalizującym stwierdzeniu, że „dzisiejsi ateiści to podwójni głupcy, nie wystarczy im bowiem, że zaprzeczają istnieniu Boga w duchu, ale bezbożność tę wypowiadają na głos i tym samym winni są podwójnej nieroztropności i nierozwagi”. Mimo tego dosyć jednoznacznego odcięcia się od ateizmu Hume przez swoich współczesnych był postrzegany i przedstawiany jako ateista. Również dzisiaj nie brakuje takich znawców jego poglądów, którzy uważają, iż był on w gruncie rzeczy ateistą i jedynie obawa przed negatywnym odbiorem jego poglądów przez jego społeczne otoczenie sprawiała, że sformułował on to zastrzeżenie do ateizmu ${ }^{14}$.

Sporo znaków zapytania pozostawia również pojmowanie i przedstawianie deizmu przez Woltera. Pojawia się ono w jego Słowniku filozoficznym pod hasłem „teista” (Théiste). W jego świetle

[...] teista to człowiek głęboko przekonany o istnieniu Najwyższego Bytu równie dobrego, jak potężnego, który stworzył wszystkie byty rozciągłe, wegetujące, czujące, myślące, który zachowuje ich gatunek, który bez okrucieństwa karze zbrodnie i z dobrocią nagradza czyny cnotliwe. Teista nie wie, w jaki sposób Bóg karze, w jaki sposób nagradza, w jaki przebacza, nie jest bowiem na tyle zuchwały, aby pochlebiać sobie, że zna sposób postępowania Boga; wie jednak, że Bóg działa i że jest sprawiedliwy. [...] Jednomyślny w tym względzie z resztą wszechświata, nie należy do żadnej sekty, które sobie wzajemnie przeczą. Jego religia jest najstarsza i najbardziej rozpowszechniona, albowiem zwykłe uwielbienie jakiegoś Boga było wcześniejsze od wszelkich systemów ${ }^{15}$.

że wątpi w istnienie prawdziwych ateistów, to stwierdził: ,jest nas tutaj osiemnastu - piętnastu to ateiści, a trzech pozostali nie podjęli jeszcze w tej kwestii decyzji”. Opis tego wydarzenia wyszedł spod pióra Denisa Diderota, który uważany był i jest nie za ateistę, lecz deistę. Por. D. Berman, A history of atheism..., s. $101 \mathrm{nn}$.

${ }^{14}$ Problem ten podjęła Keith E. Yandal, stawiając pytanie: czy Hume był ateistą? Interesująca jest nie tylko jej odpowiedź (raczej przecząca niż twierdząca), ale także przywoływane przez nią stanowiska innych autorów w tej kwestii, takich jak James Noxon, który uznaje Hume’a za agnostyka, Nicholas Capaldie, który uznaje go za „apofatycznego teistę”, czy George Nathan, który uważa, że „Bóg Hume’a jest w immamenty w świecie”, jednak jego stanowisko „trudno jest odróżnić od ateizmu”. Por. K.E. Yandal, Was Hume an Atheist?, w: W. Hudson, D. Luccl, J.R. Wilgelsworth (eds), Atheism and Deism Revalued..., s. 191 nn.

${ }^{15}$ Por. Voltaire, Dictionnaire philosophique, Edition Flammarion, Paris 2010, hasło: Théiste. Paul Hazard w komentarzu do deizmu tego filozofa stwierdza, że to Voltaire „uprzystępnił deizm, oddając na jego usługi cały swój artyzm. [...] Odebrał deizmowi arystokratyczny i quasi-sceptyczny charakter, jaki nadał mu Bolingbroke, poetyckość, którą nadał mu Pope, i związał go ściśle z życiem, z działaniem”. Natomiast nieco dalej dodaje, że „deizm francuski, podając ponad głową Pope’a rękę deizmowi Tolanda i Collinsa, był z istoty swej agresywny”. Por. P. Hazard, Myśl europejska w XVIII wieku..., s. 355 nn. 
Z tych i podobnych im Wolterowskich sformułowań można oczywiście wyprowadzić różne uogólnienia dotyczące zarówno pojmowania i przedstawiania deizmu przez tego filozofa, jak i kłopotów związanych nie tylko z tym deizmem, bowiem i ta wypowiedź, i szereg innych jego wypowiedzi ma wieloznaczny charakter. Pewne dopowiedzenia w kwestii Wolterowskiego deizmu można znaleźć w zamieszczonym w tym samym Słowniku filozoficznym haśle „natura” (Nature). Napisane jest ono w formie dialogu między Naturq i Filozofem - ten ostatni stawia jej szereg pytań (dotyczących takich zasadniczych kwestii, jak jej kreacyjna moc czy rozumność), natomiast ta druga wprawdzie udziela na nie odpowiedzi, ale są one w gruncie rzeczy wymijające. Takie dopowiedzenia można również znaleźć w Wolterowskim traktacie Elementy filozofii Newtona. Już w jego pierwszym rozdziale, zatytułowanym O Bogu, Wolter przypisuje Isaacowi Newtonowi deizm. Jego zdaniem ten uczony i filozof angielski „był głęboko przekonany o istnieniu Boga, rozumiał zaś przez to słowo nie tylko Istotę nieskończoną, wszechmocną, wieczną i twórczą, lecz również Pana, który ustanowił pewien stosunek pomiędzy sobą a swymi stworzeniami; bez tego bowiem stosunku poznanie Boga jest tylko jałową ideą, która w ludziach skłonnych do przewrotnego mędrkowania budzić może nadzieję na bezkarność i przez to zachęcać ich do zbrodni”16. Stanowi to wprawdzie pewne dopełnienie dla Wolterowskiego stwierdzenia, że „gdyby nawet Boga nie było, to należałoby go wymyśleć”, ale raczej w małym stopniu oddaje faktyczne stanowisko Newtona. To ostatnie sytuuje się bowiem na gruncie teizmu i to tak głębokiego, że prowadzącego tego uczonego do przekonania, że osiągnął swoistą unio mistyka z Bogiem ${ }^{17}$.

W przywoływanej już tutaj monografii na temat ateizmu i deizmu lat 1650-1800 można znaleźć szereg interesujących sugestii na temat inspirowania przez deistów tamtego okresu ówczesnych rewolucji społecznych - zarówno amerykańskiej z drugiej połowy XVIII stulecia, jak i francuskiej z 1789 r. Kerry Walters mówi wręcz o „,rewolucyjnych deistach” i zalicza do nich takich ich przedstawicieli, jak: we Francji Mirabeau, Sieyès, Brissot, Condorcet, Volney i Desmoulins, a w Ameryce Franklin, Paine, Palmer, Madison i Jefferson ${ }^{18}$. Warto zwrócić uwagę na to,

${ }^{16}$ Nieco dalej dodaje on, że „cała filozofia Newtona z konieczności prowadzi do poznania jakiejś Istoty Najwyższej, która wszystko stworzyła, wszystko urządziła podług swej woli”. Por. Voltaire, Elementy filozofii Newtona, PWN, Warszawa 1956, s. 5 nn.

${ }_{17}$ Jego biograf Frank E. Manuel pisze, że to przekonanie o nawiązaniu „bezpośredniego, osobistego kontaktu z Bogiem, jego Ojcem”, przez „wiele lat dodawało mu sił do wytężonej pracy intelektualnej w Cambridge”. Dodaje on przy tym, że „mimo kłopotów ze zrozumieniem religijnych wypowiedzi Newtona [...], z pewnością można stwierdzić, iż nie był on zwolennikiem ani zwykłego mechanistycznego poglądu na świat, ani deistycznej religii naturalnej. Za złośliwość ujść może powoływanie się na takiego bezbożnego światka jak Wolter”. Por. F.E. Manuel, Portret własny Newtona, Wydawnictwo Prószyński i S-ka, Warszawa 1998, s. 130 i in.

18 „Ateizm i deizm mogą się pod pewnymi względami bardzo różnić, jednak jak pokazał Camille Desmoulins w rewolucyjnej broszurce La France Libre z sierpnia 1789 r., to, co naprawdę liczyło się w awansowaniu demokratycznego republikanizmu, to była eliminacja boskiej 
że w preambule takiego sztandarowego dokumentu rewolucji francuskiej 1789 r. pojawia się nie odwołanie do katolickiego Boga, lecz do bliżej nieokreślonej Istoty najwyższej (Etre suprème), natomiast w jej w art. X (i tylko w nim) jest niewielka wzmianka na temat religii i religijności (mówi się w nim, że „nikt nie powinien być niepokojony z powodu swoich przekonań, nawet religijnych”) ${ }^{19}$. W przypadku ojców-założycieli Stanów Zjednoczonych Ameryki Północnej niektórych z nich uznaje za takich chrześcijańskich teistów, u których pojawiają się jedynie pewne „tendencje deistyczne”, natomiast innych za deistów ${ }^{20}$. Do tych ostatnich zalicza się m.in. Benjamina Franklina; on sam w swojej Autobiografii określa siebie jako „dokładnego deistę” (thorough Deist) ${ }^{21}$. W preambule uchwalonej w 1787 r. i przyjętej dwa lata później Konstytucji Stanów Zjednoczonych nie pojawia się żadna Najwyższa Istota (w głównej roli występuje w niej Naród Stanów Zjednoczonych). Nie ulega jednak wątpliwości, że jej artykuły i paragrafy formułowane są w duchu deistycznym. Znalazł on wyraz również w poprawka do tego aktu prawnego, w tym w przyjętej 15 grudnia 1791 r. pierwszej poprawce („zakazuje ograniczania wolności religii, prasy, słowa, petycji i zgromadzeń”).

Trzeba wyraźnie powiedzieć, że ani w przeszłości, ani obecnie opowiadanie się za deizmem nie miało charakteru masowego. Wskazanie liczby deistów przeszłości utrudniają nie tylko ich niejednoznaczne deklaracje, ale także zróżnicowanie deizmu oraz jego mniej lub bardziej wyraźne związki z panteizmem²2. Obecnie takie deklaracje są wprawdzie bardziej jednoznaczne i śmiałe, jednak niejednokrotnie trudno jest wskazać różnice i granice miedzy deizmem i agnostycyzm. Takie badania były oczywiście prowadzone, m.in. w Stanach Zjednoczonych przez American Religious Identification Survey (ARIS) w 2008 r. na próbie ok. 50 tys. respondentów - 70\% z nich deklarowało swoją wiarę w osobowego Boga, 12\% deklarowało ateizm i agnostycyzm, natomiast $12 \%$ wiarę w istnienie jakieś nieosobowej siły wyższej ${ }^{23}$. W 1993 r. założony został przez Boba Johnsona Światowy Związek Deistów (World Union of Deists, WUD), wydający czasopismo „Myśl”

opatrzności i zaprzeczenie istnienia takiego Boga, który rządzi biegiem historii oraz nagradza i karze ludzi za ich czyny”. Por. Introduction, w: W. Hudson, D. Luccl, J.R. Wilgelsworth (eds), Atheism and Deism Revalued..., s. XXX nn.

${ }^{19}$ Por. Les déclarations des droits de l'homme de 1789. Textes réunions et présentés par Christine Fauré, Editions Payot, Paris 1988, s. 11 nn.

${ }^{20}$ Por. K.S. Walters, The American Deists: Voices of Reason \& Dissent in the Early Republic, University of Kansas Press, 1992.

${ }^{21}$ Por. Autobiography of Benjamin Franklin, Macmillan, New York 2011.

${ }^{22}$ W literaturze wyróżnia się m.in. deizm klasyczny, deizm chrześcijański, deizm naukowy i deizm humanistyczny. Por. M. Epstein, Postatheism and the phenomenon of minimal religion in Russia, w: J. Beaumont (ed.), The Routledge Handbook of Postsecularity, 2018, s. 83 i in.

${ }^{23}$ Por. American Religious Identyfication Survey 2008, Summary Report, March 2009, B.A. Kosmin, A. Keysar, Trinity College, https://commons.trincoll.edu/aris/publications/2008-2/ aris-2008-summary-report/ [18.03.2017]. 
(„Think”), oraz propagujący deizm na swojej stronie internetowej deism.com ${ }^{24}$. W roku 2010 założony został niepowiązany z WUD Kościół Deizmu. W obiegu czytelniczym pojawiają się również publikacje deistów nienależących do żadnej deistycznej organizacji. Przykładem może być opublikowana w 2007 r. książka Roberta Corfe'a pt. Deism and Social Ethics ${ }^{25}$.

W Polsce deizm jest niejednokrotnie słabo odróżnialny nie tylko od agnostycyzmu, ale także od ateizmu, i to nie tylko przez ludzi Kościoła, ale także przez świeckich uczonych. Potwierdzeniem tego są m.in. badania nad tym, w co wierzą polscy uczeni przeprowadzone przez Marię Libiszowską-Żótkowska w roku 1997 na próbie 447 respondentów należących do grupy profesorów zatrudnionych na polskich wyższych uczelniach. Wśród nich deizm deklarowały 34 osoby. W prezentującej wyniki tych badań książce znajdują się również krótkie konkretyzacje kilku z nich. Przykładowo: jeden z nich stwierdził, że „wierzy w istnienie sacrum, rzeczywistości duchowej wykraczającej poza tu i teraz, ale niekoniecznie musi to być siła sprawcza”, natomiast inny określił się jako „umiarkowany deista traktujący sprawy religii jako bardzo osobisty problem”26.

Jeszcze kilka słów o stosunku współczesnych ateistów do deistów. Jest on wprawdzie zróżnicowany, jednak można powiedzieć, że podobnie jak w przypadku teistów - z im bardziej radykalnym ateizmem mamy do czynienia, tym większe jest banalizowanie przez nich deizmu. Można się o tym przekonać, sięgając chociażby po Boga urojonego, dzieło radykalnego ateisty, jakim jest Richard Dawkins. Jego zdaniem, o ile jeszcze panteizm zasługuje na pewne uznanie (jest to bowiem w gruncie rzeczy „,ateizm podzielony na kategorie”), to nie zasługuje na nie deizm (jest to bowiem „rozwodniony teizm”) ${ }^{27}$. Bardziej umiarkowany ateizm reprezentuje Michael Ruse. Przekłada się to m.in. na przychylniejszą ocenę deizmu - w swojej książce pt. Ateizm twierdzi on, że „patrząc z perspektywy czasu, z pewnością da się

${ }^{24}$ W znajdującej się na niej definicji deizmu stwierdza się, że „deizm jest uznaniem uniwersalnej siły twórczej większej niż ta wykazywana przez ludzkość, poparte osobistą obserwacją praw i planów w przyrodzie i we wszechświecie, utrwalone i potwierdzone przez wrodzoną zdolność ludzkiego rozumu i połączone z odrzuceniem roszczeń osób i zorganizowanych religii powołujących się na boskie objawienie”. W 2009 r. opublikowana została przez WUD książka Boba Jonsona pt. Deism: A Revolution in You, natomiast w 2010 r. książka pt. An Answer to Mere Christianity C.S. Lewisa, która stanowi polemikę z wymienionym w jej tytule apologetą religii chrześcijańskiej.

${ }^{25}$ Jej autor jest amerykańskim politologiem, socjologiem i biznesmenem (pracującym na stanowisku menedżera w różnych krajach na Bliskim Wschodzie. W książce tej przedstawia on deizm jako taką światową religię, która jest w stanie położyć kres tym światowym konfliktom, które mają swoje źródło w różnych wierzeniach religijnych. Krytyczną analizę tej wizji deizmu można znaleźć w artykule A. Szweda pt. Krytyka pewnej postaci współczesnego deizmu jako projektu nowej religii w zglobalizowanym świecie, „Roczniki Filozoficzne” 4/2017.

${ }^{26}$ Por. M. Libiszowska-Żótkowska, Wiara uczonych. Esej socjologiczny mocno osadzony w empirii, Wydawnictwo Nomos, Kraków 2000, s. 95 i in.

${ }^{27}$ Por. R. Dawkins, Bóg urojony, CIS, Warszawa 2007, s. 40 i in. 
zauważyć, że deizm był po prostu przystankiem na drodze do ateizmu. W aspekcie metodologicznym Bóg jest na emeryturze. Wystarczy jeden krok i przejdzie on także na emeryturę metafizyczną"28.

\section{Literatura}

American Religious Identification Survey 2008, Summary Report, March 2009, B.A. Kosmin, A. Keysar, Trinity College, https://commons.trincoll.edu/aris/publications/2008-2/ aris-2008-summary-report/ [18.03.2017].

Autobiography of Benjamin Franklin, Macmillan, New York 2011.

Bergman D., A History of Atheism in Britain, Routledge, London and New York 2013.

Cassirer E., An essay on man; an introduction to a philosophy of human culture, Yale University Press 1944.

Disraeli B., Whigs and Whiggism: political writings, Macmillan 1914.

Dawkins R., Bóg urojony, CIS, Warszawa 2007.

Fauré Ch. (ed.), Les déclarations des droits de l'homme de 1789, Editions Payot, Paris 1988. Gay P., Deism: An Anthology, D. Van Nostrand Company, Inc., Princeton 1968.

Epstein M., Postatheism and the phenomenon of minimal religion in Russia, w: J. Beaumont (ed.), The Routledge Handbook of Postsecularity, 2018.

Hazard P., Myśl europejska w XVIII wieku. Od Monteskiusza do Lessinga, PIW, Warszawa1972.

Himmelfarb G., The Roads to Modernity. The British, French, and American Enlightenments, Alfred A. Knoff, New York, 2004.

Herbert of Cherbury, De Veritate, J.W. Arrowsmith, Bristol 1937.

Hudson W., Luccl D., Wilgelsworth J.R. (eds), Atheism and Deism Revalued. Heterodox Religoius Identities in Britain, ASHGATE Press, Burligton 2014.

Hugh Ch., Herbert of Cherbury, Edward Herbert, Baron, „Encyclopædia Britannica” 13, wyd. 11, Cambridge University Press 1911.

Hume D., Dialogi o religii naturalnej, PWN, Warszawa 1962.

Libiszowska-Żótkowska M., Wiara uczonych. Esej socjologiczny mocno osadzony w empirii, Wydawnictwo Nomos, Kraków 2000.

Manuel F.E., Portret własny Newtona, Wydawnictwo Prószyński i S-ka, Warszawa 1998. Orr J., English Deism: Its Roots and Its Fruits, 1934.

Ruse M., Ateizm. Co każdy powinien wiedzieć?, Wydawnictwo Uniwersytetu Łódzkiego, Łódź 2016.

Szwed A., Krytyka pewnej postaci współczesnego deizmu jako projektu nowej religii w zglobalizowanym świecie, „Roczniki Filozoficzne” 4/2017.

${ }^{28}$ Nieco dalej stawia pytanie: „dlaczego deizm nie chciał ustąpić?” (miejsca ateizmowi). W odpowiedzi na nie stwierdza, że przykładowo „dla kogoś takiego jak Franklin, religia splatała się z funkcjonowaniem ludzi w grupach i religię w takiej czy innej formie postrzegał jako niezbędną dla zdrowego społeczeństwa. [...] Nie popadając jednak w nadmierne uogólnienia, da się wyraźnie powiedzieć, że głównym czynnikiem trzymającym ludzi z dala od całkowitej niewiary był problem organizmów. Boyle stwierdził to jasno. Świat może przypominać maszynę, ale organizmy wymagają myślenia w kategoriach przyczyn celowych”. Por. M. Ruse, Ateizm. Co każdy powinien wiedzieć?, Wydawnictwo Uniwersytetu Łódzkiego, Łódź 2016, s. 35 i in. 
Viret P., Instruction Chrétienne en la doctrine de la foi et de l'Évangile, Editions l'Age d'Homme, Paris 2004.

Voltaire, Dictionnaire philosophique, Edition Flammarion, Paris 2010.

Voltaire, Elementy filozofii Newtona, PWN, Warszawa 1956.

Waligore J., The Piety of the English Deists, „Intellectual History Review” 2(22)/2012.

Walters K.S., The American Deists: Voices of Reason \& Dissent in the Early Republic, University of Kansas Press, 1992. 